PROCEEDINGS OF UNITED STATES NATIONAL MUSEUM. 541

Table of measurements-Continued.

\begin{tabular}{|c|c|c|c|c|c|c|}
\hline Fpecies .... & \multicolumn{2}{|c|}{$\begin{array}{l}\text { Citharichthys } \\
\text { macrops. }\end{array}$} & \multicolumn{2}{|c|}{$\begin{array}{l}\text { Citharichthys } \\
\text { microstomus. }\end{array}$} & \multicolumn{2}{|c|}{$\begin{array}{l}\text { Citharichthys } \\
\text { spilopterus. }\end{array}$} \\
\hline 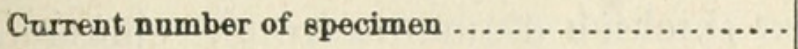 & \multicolumn{2}{|c|}{21500 (type). } & \multicolumn{2}{|c|}{36081.} & \multicolumn{2}{|c|}{35099.} \\
\hline \multirow[t]{2}{*}{ Locality ... } & \multicolumn{2}{|c|}{ Pensacola, Fla. } & \multicolumn{2}{|c|}{$\begin{array}{l}\text { Great South } \\
\text { Bay, Long Is- } \\
\text { land, N. Y. }\end{array}$} & \multicolumn{2}{|c|}{ Havana, Cuba. } \\
\hline & millim. & $\begin{array}{c}\text { 100ths } \\
\text { of } \\
\text { length. }\end{array}$ & millim. & $\begin{array}{c}100 \text { ths } \\
\text { of } \\
\text { length. }\end{array}$ & millim. & $\begin{array}{l}100 \text { ths } \\
\text { of } \\
\text { length. }\end{array}$ \\
\hline $\begin{array}{l}\text { Pectoral: } \\
\text { Distance from snont....... }\end{array}$ & 25 & 25 & 20 & 22.8 & & \\
\hline Length $\left\{\begin{array}{l}\text { sinistral } \ldots . . . . . . \\
\text { dextral .......... }\end{array}\right.$ & 16 & 16 & 16 & 18.4 & 13 & 14 \\
\hline $\begin{array}{l}\text { Ventral: } \\
\text { Distance from snout }\end{array}$ & 12 & 12 & 10 & 11.4 & $11+$ & 12 \\
\hline $\begin{array}{l}\text { Distance from snout........ } \\
\text { Length on blind side ...... }\end{array}$ & $\begin{array}{l}24 \\
10\end{array}$ & $\begin{array}{l}24 \\
10\end{array}$ & $\begin{array}{l}20 \\
10\end{array}$ & $\begin{array}{l}22.8 \\
11.4\end{array}$ & $\begin{array}{c}25 \frac{1}{2} \\
8\end{array}$ & $\begin{array}{r}27.3 \\
8.7\end{array}$ \\
\hline 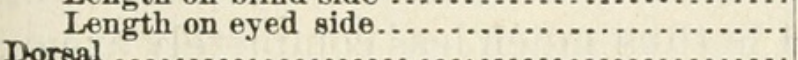 & 9 & 9 & 9 & 10.3 & 71 & 3 \\
\hline $\begin{array}{l}\text { Doreal } \\
\text { Anal }\end{array}$ & 80 & $\ldots \ldots \ldots$ & 76 & 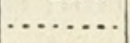 & $81^{3}$ & \\
\hline 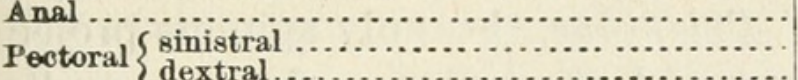 & $\begin{array}{l}56 \\
11\end{array}$ & $\begin{array}{ll}\cdots \cdots \\
\cdots \cdots \cdots\end{array}$ & $\begin{array}{l}57 \\
10\end{array}$ & …...... & $\begin{array}{l}62 \\
10\end{array}$ & -......... \\
\hline 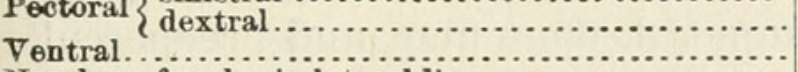 & 9 & $\cdots \cdots$ & $\begin{array}{r}10 \\
9\end{array}$ & $\cdots \cdots \cdot \cdot$ & $\begin{array}{r}10 \\
9\end{array}$ & (........... \\
\hline 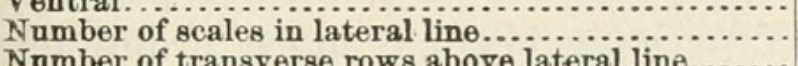 & $\begin{array}{r}6 \\
41\end{array}$ & an. & $\begin{array}{r}6 \\
41\end{array}$ & an. & $\begin{array}{r}6 \\
46\end{array}$ & $\begin{array}{ll}2 \ldots \\
\cdots \cdots \cdots\end{array}$ \\
\hline $\begin{array}{l}\text { Number of transverse rows above lateral line....... } \\
\text { Number of transverse rows below lateral line...... }\end{array}$ & 14 & ......... & 10 & & .......... & ....... \\
\hline 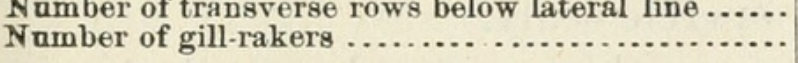 & $6+13$ & & $\begin{array}{r}14 \\
4+6\end{array}$ & & $\dddot{5}+10$ & $\begin{array}{l}\cdots \\
\ldots \ldots\end{array}$ \\
\hline
\end{tabular}

November 26, 1884.

\title{
DESCRIPTION OF THREE NEW SPECIES OF FISHES (PRIONOTUS STEARNSI, PRIONOTUS OPHRYAS, AND ANTHIAS VIVANUS) COLLECTED AT PENSACOLA, FLORIDA, BY MR. SILAS STEARNS.
}

\section{BY DAVID S. JORDAN RAd JOSEPH SWAIN.}

Prionotus stearnsi, sp. nov. (No. 36943.)

Head $2 \frac{2}{3}$ in length ( $3 \frac{1}{3}$ including caudal); depth $4(5) ;$ D. VIII -12 ; A. 12. Scales (transverse series), 77 ; pores in lateral line about 48 . Inength, $3 \frac{3}{8}$ inches.

Allied to Prionotus evolans.* Body not very slender; narrowed but compressed above, the width of the nape between the occipital spines being about one-fifth the head. Head depressed and long, its upper profile being a little concave before eye, thence slightly convex or almost straight to front of dorsal. Snout $2 \frac{1}{2}$ in head, not very broad, rather more than usually rounded anteriorly and scarcely emarginate at tip. Edges of snout without spine and without distinct serræ, the margin merely granular. Surfaces of bones of head comparatively smooth, but roughened with small granules, which are arranged in radiating striæ, much as in $P$. evolans, but more regularly than in that species.

* Prionotus sarritor Jordan \& Gilbert, Proc. U. S. Nat. Mus., 1882, 615. The type of Trigla evolans L. in London has been examined by Dr. Bean. It is apparently identical with $P$. sarritor. 
Mouth rather wide, the maxillary reaching to opposite front of the eye, the mandible about to center of eye; maxillary 2 in head. Bands of palatine teeth narrow,

Eye small, its diameter (in young specimen) $4 \frac{2}{3}$ in head. A very small cirrus formed of two or three thickish filaments from a common base on upper part of eye; its length little more than half the pupil. Interorbital area of moderate width, rather deeply concave, its least width $6 \frac{1}{2}$ in head. Orbital rim not at all elevated, its bones with entire or granulated edges. No trace of spine or groove behind eye. Occipital spines very weak, the outer pair inconspicuous, not reaching nearly to front of dorsal, the inner pair altogether wanting, no trace of them being seen. No spines, ridges, or evident roughness on temporal region. Preopercle with a single small spine, without smaller one at its base. Lower opercular spine small; upper opercular spine reduced to a blunt point. Humeral spine inconspicuous, not extending beyond opercular spine. The head is thus much less completely armed than in any other of our species of Prionotus, the only spinous projections present being the occipital, humeral, opercular, and preopercular spines, 4 pairs. These spines may perhaps become more prominent with age. Membranaceous flap of opercle scaly.

Gill-rakers long and very slender, about thirteen developed, the length of the longest about half eye.

Scales rather large, those on the nape and breast little reduced in size; about 10 between dorsal and occiput.

Fins all low and small. First dorsal spine rather the highest, its length $2 \frac{1}{3}$ in head, its anterior margin serrulate. Longest ray of soft dorsal, 2 in head. Caudal, $1 \frac{1}{3}$ in head. Longest anal ray, 2 in head. Pectorals very short (perhaps longer in the adult), reaching only to front of second dorsal, $1 \frac{1}{4}$ in head. Detached rays slender, the uppermost $1 \frac{7}{8}$ in head. Ventrals, $1 \frac{1}{5}$ in head.

Color in spirits, brown, paler below; scales everywhere with dark punctulations, these forming a darker shade on the lateral line near the middle of the body; head plain brown. Spinous dorsal dusky posteriorly. Soft dorsal with two dusky longitudinal shades. Caudal blackish at tip. Anal with a Llack stripe toward the margin. Pectorals black, the detached rays and ventral fins plain whitish.

The type of this species, $3 \frac{3}{8}$ inches long, in good condition, was "spewed up" by a red snapper (Lutjanus vivanus), at Pensacola.

\section{Prionotus ophryas, sp. nov. (No. 36944.)}

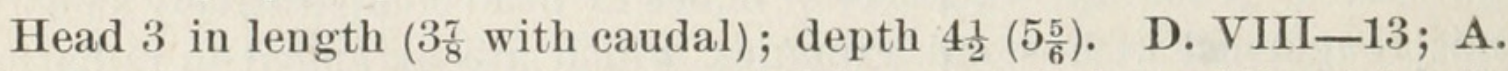
11. Scales (transverse series, about), 75 ; pores in lateral line (about), 50. Length $7 \frac{1}{4}$ inches.

Allied, but not closely, to Prionotus tribulus. Body rather slender, narrower anteriorly and more compressed above than in other species, 
the width of the nape between the outer pair of occipital spines being not quite one-fourth the length of the head. Upper profile of head peculiar, being nearly straight from above front of eye backward, and steep and strongly concave from front of eye to tip of snout. The snout is, therefore, steeper, more depressed, and rather shorter than in related species, its length being $2 \frac{1}{4}$ in head. Snout not very broad, its front broadly rounded, its tip, as usual, emarginate, its edge with fine serræ directed backward, but no spines. Surfaces of bones of the head covered with fine, sharply-defined striæ, but with none of the small granulations which are found in $P$. strigatus and other species.

Mouth rather wide, the maxillary reaching nearly to front of eye, the mandible quite to front of eye. Maxillary, 21 in head. Band of palatine teeth of moderate length, as long as eye.

Eye large, placed high, its diameter $4 \frac{1}{2}$ in head. Upper part of eye with a fleshy cirrus rather enlarged toward the tip and fringed. This resembles the cirri in Scorpona ; its length is about half that of the eye. Interorbital area very narrow and very deeply concave, its least width little more than one-eighth the length of the head and not two-thirds the length of the eye. Depth of interorbital area nearly one-third length of' eye. Bone forming anterior portion of orbital rim very prominent, forming a strongly striated erest, each of the striæe ending in a projecting point or spinule. Upper portion of orbital rim prominent, even, ending behind the eye in a sharp backward-directed spine, behind which is a short cross-groove, which does not extend across the top of the head. Distance from the base of this spine to the scales on the nape very short, not more than half the length of the eye. Both pairs of occipital spines distinct, the outer and larger ones extending to oppo site front of dorsal. A small spine on temporal region in front of outer pair of spines. Preopercle with a single moderate spine, at the end of a long ridge; no smaller spine at its base. Opercle strongly striate, with two strong spines, of which the upper one is proportionately larger than usual. A single, rather strong humeral spine; membranaceous flap of opercle scaly.

Gill rakers very short and thick, about 9 developed, these not half longer than the interspaces, and not one-fourth length of eye. They are abeut half as broad as high, thus having a form very different from that seen in P. evolans, P. strigatus, P. tribulus, \&c.

Scales rather large, the scales on the back little reduced in size (about 10 between occiput and dorsal fin; 17 in P. strigatus).

Dorsal spines high and rather slender, the first rather the highest, its length $1 \frac{1}{2}$ in head, its anterior margin not granulated. Soft dorsal rather high, its longest ray 2 in head. Caudal $1 \frac{1}{3}$ in head; longest anal ray $2 \frac{1}{3}$ in head. Pectorals rather long, extending nearly to last rays of dorsal, their length almost twice head. Detached rays moderate, the uppermost or longest $1 \frac{1}{3}$ in head. Ventrals $1 \frac{1}{6}$ in head.

Coloration largely faded in the typical example; apparently olive- 
brown above, with some vague darker cross-shades; pale below; caudal with two dark cross-bands; pectoral dusky; the free rays with - dusky spots; rentrals pale, with some dusky bands; coloration of dorsal and anal mostly lost; apparently much as in P. strigatus; head nearly plain; the cirri dark.

This species is described from one specimen, $7 \frac{1}{4}$ inches long, in fair condition, but with the membranes of the fins somewhat digested. It was taken from the stomach of a red snapper (Lutjanus vivanus), at Pensacola, by Mr. Silas Stearns. The short gill-rakers, and deeply concave interorbital area, distinguish this species at once from all others.

The collection in which these two species of Prionotus were included, contained among other interesting species the following:

\section{Seriola dumérili Risso.}

Anthias vivanus, sp. nov. (No. 36942.)

Body oblong, elliptical, strongly compressed; the snout rather short, and anteriorly pointed; the profile from snout to dorsal quite steep, and very slightly convex; back gently arched; its curve corresponding very nearly with that of the beliy. Snout rather shorter than eye, which is $3 \frac{1}{3}$ in head ; mouth oblique, the lower jaw projecting (upper jaw mutilated); cleft of mouth extending to below front of pupil; its length, $2 \frac{3}{4}$ in head; interorbital area convex; its width about three-fourths eye; lower jaw with small, fixed, backward turned teeth, mostly in one row; two small recurved canines on side of lower jaw, near the front, and one on each side near the symphysis; preopercle sharply serrate; the tooth at the angle considerably enlarged, projecting backward; lower limb entire, except near the angle; operele with two sharp spines, besides an acute flat point; the uppermost spine longest. Gill-rakers very long and slender, almost setiform, numerous, and close set.

Scales of moderate size, weakly ctenoid (those on head mostly lost). Lateral line strongly arched, concurrent with the back and running very close to the dorsal fin, under the middle of the spinous dorsal, falling abruptly under last rays of soft dorsal to middle of caudal peduncle, thence straight to base of caudal fin.

Dorsal spines low, rather strong, none of them filamentous, gradually increasing in length to the fourth, which is $2 \frac{1}{3}$ in head, thence growing slowly shorter to the ninth, which is 4 in head. Soft dorsal and anal moderately elevated, their last rays somewhat more than half head and nearly reaching base of caudal. Second anal spine about as long as third, $2 \frac{3}{4}$ in head (caudal and ventral fins mutilated). Pectoral fin well developed, a little shorter than head. Color in spirits, olivaceous above, somewhat rosy below; back, with numerous faint narrow olivaceous cross shades, formed of dark points. Head and fins plain.

Head, $3 \frac{3}{5}$; depth, $3 \frac{1}{8}$. D. X, 13 ; A. III, 8. Scales, 21-43-12.

A single specimen, about $2 \frac{1}{2}$ inches long, was taken from the stomach of a red snapper (Lutjanus vivanus) at Pensacola by Silas Stearns. This 


\section{Vol. VII, No. 35. Washingtom, D. C. Feb. $16,1885$.}

species is allied to Antheas multifasciatus Gill, described from Cape San Lucas.

Serranus, sp. nov.

A single specimen from which most of the skin and scales has been digested. It is allied to S. bivittatus C. \& V.

Lobotes surinamensis Bloch.

Decodon puellaris Poey.

Pomacentrus caudalis Poey. (No. 36945.)

(Synopsis Piscium Cubensium 1868, 328.)

One specimen in good condition. Head, $3 \frac{1}{2}$ in length; depth, $2 \frac{1}{6}$. D. XII, 14; A. II, 13. Scales, 4-29-9. Upper parts dusky; the greater part of each scale of a light grayish blue; lower parts bright yellow, with some blue spots on the scales; top and sides of head similarly marked with bluish spots on the scales. A jet black, ink-like spot, ocellated with blue on the back of the tail. Dorsal fin colored like the back; the posterior soft rays abruptly yellow. Caudal fin bright yellow, lower fins chiefly yellow.

Form oblong-ovate; the anterior profile moderately convex. Preorbital and preopercle well serrated. Teeth moderate, entire. Soft parts of dorsal and anal rather high.

This is the first record of this rare species on our coasts.

Porichthys porosissimus Cuv. \& Val.

INDIANA UNIVERSITY,

December 4, 1884.

\section{SUPPLEMENTARY NOTES ON NORTH AMERICAN FISHES.}

RY DA VID S. JORDAN.

The following notes on points connected with North American ichthyology are mostly supplementary to statements contained in different papers published by the writer in these Proceedings for the current year 1884 .

\section{Cryptotomus, Cope.}

On page 100, Proc. U. S. Nat. Mus., 1884, we observe, "It seems to us almost certain that either Professor Cope has mistaken two of the soft rays of the dorsal and one of the anal for spines, or else that these rays are, in the single specimen (of Cryptotomus roseus) known, abnormally ossified." Since this was written I have examined Professor Cope's type of Cryptotomus roseus, and I find the former supposition to be correct. This specimen has nine dorsal and two anal spines.

Proc. Nat. Mus. $85-35$ 


\section{$2 \mathrm{BHL}$ Biodiversity Heritage Library}

Jordan, David Starr and Swain, J. 1885. "Description of three new species of fishes (Prionotus stearnsi, Prionotus ophryas, and Anthias vivanus) collected at Pensacola, Florida, by Mr. Silas Stearns." Proceedings of the United States National Museum 7, 541-545. https://doi.org/10.5479/si.00963801.7-465.541.

View This Item Online: $\underline{\text { https://www.biodiversitylibrary.org/item/31798 }}$

DOI: https://doi.org/10.5479/si.00963801.7-465.541

Permalink: https://www.biodiversitylibrary.org/partpdf/11592

\section{Holding Institution}

Smithsonian Libraries

\section{Sponsored by}

Smithsonian

\section{Copyright \& Reuse}

Copyright Status: NOT_IN_COPYRIGHT

This document was created from content at the Biodiversity Heritage Library, the world's largest open access digital library for biodiversity literature and archives. Visit BHL at https://www.biodiversitylibrary.org. 